\title{
Customer experience perspective in majapahit house management in Bejijong Village, Mojokerto
}

\author{
Gunawan Christanto \\ Faculty of Business and Economics, University of Surabaya \\ Gunawan5122@gmail.com \\ Erna Andajani \\ Faculty of Business and Economics, University of Surabaya \\ ernajadi@staff.ubaya.ac.id
}

Received: May, 2021; Accepted: July, 2021; Published: September, 2021
DOl: $\underline{\text { https://doi.org/10.24123/imb.v20i2 }}$

\begin{abstract}
This study aims to explore the perspective of customer experience in managing Majapahit House in Bejijong Village by explaining the phenomena that are being the questions of the study. Then to explain the phenomena that occur, this study uses a qualitative method with a phenomenological paradigm. The results of this study indicate the views of managers and tourists towards activities that refer to three conditions: before, during the service delivery process and the service has been provided. This research is useful for business managers, especially related to the field of tourism to see the importance of managing customer experience.
\end{abstract}

Keywords: Customer experience, Rural tourism, Service.

\begin{abstract}
Abstrak
Penelitian ini bertujuan untuk mengeksplorasi perspektif pengalaman pelanggan dalam pengelolaan Rumah Majapahit di Desa Bejijong dengan menjelaskan fenomena yang menjadi pertanyaan dari penelitian. Kemudian untuk menjelaskan fenomena yang terjadi, penelitian ini menggunakan metode secara kualitatif dengan paradigma fenomenologi. Hasil dari penelitian ini menunjukkan pandangan pengelola dan wisatawan terhadap kegiatan yang mengacu pada tiga kondisi: sebelum, saat proses penyampaian layanan dan layanan telah diberikan. Penelitian ini bermanfaat bagi pengelola bisnis khususnya terkait bidang pariwisata untuk melihat pentingnya dari mengelola pengalaman pelanggan.
\end{abstract}

Kata Kunci: Pengalaman pelanggan, Pariwisata pedesaan, Layanan

\section{INTRODUCTION}


Kampung Majapahit is a tourist village area which is classified as urban heritage. Kampung Majapahit itself is a cultural heritage area (urban heritage) located in Mojokerto Regency. Based on written evidence, Kampung Majapahit as cultural heritage is confirmed by the Decree of the Minister of Education number 260/M/2013. In the decision of the Minister of Education, it was mentioned that Kampung Majapahit is a cultural heritage area through a heritage site from the Majapahit Kingdom era. In addition, based on the Master Plan for Regional Tourism Development (RIPPDA) of Mojokerto Regency in 2007 regarding cultural tourism and historical heritage, Mojopahit Park was then developed.

Bejijong Village is the core for the development of Kampung Majapahit. This is because the potential of the Majapahit site owned by Bejijong Village is the most abundant compared to other villages. Sites in Bejijong Village include Brahu Temple Site, Siti Inggil Tomb (Tomb of Raden Wijaya) and Vihara Majapahit (Buddhist Statue). Moreover, the potential that exists in Bejijong Village is the potential for sculpture, batik, cast brass and copper (Ardika, 2003).

Based on information from the manager of Majapahit House, the number of visits (renting homestays) continued to increase from 2016 to 2019. Concrete steps to support tourism attractiveness in Bejijong Village were pioneered by the Head of Sanggar Bhagaskara (Supriyadi) through the implementation of the Kampung Majapahit Cultural Festival. Based on the explanation from Supriyadi (2019), the Cultural Festival event is held using a different theme every month. In addition, the implementation also involves local art figures and children to awaken the soul of loving art from an early age. The Kampung Majapahit Cultural Festival itself is held every Legi (Javanese calendar) Sunday. Futhermore, together with local Homestay associaton, Mr. Supriyadi also made various tour packages, information center facilities, rabbit trains and so on to add to the attraction and make it easier for tourists to find and visit various tourism potentials and industrial centers in Trowulan district.

Table 1. Average Stay and Occupancy Rate

\begin{tabular}{lll}
\hline \multicolumn{1}{c}{ Year } & Average Time Stay/Year & Occupancy Rate \\
\hline 2017 & 15 days & $4.1 \%$ \\
2018 & 22 days & $6.02 \%$ \\
2019 & 30 days & $8.21 \%$ \\
1 Jan - 15 Mar 2020 & 20 days & $27.02 \%$ \\
\hline
\end{tabular}

Source: Data of Secretary of Homestay association, 2020

The implementation of the Kampung Majapahit Cultural Festival is a strategic step to create a multiplier effect in Bejijong Village. Besides introducing Kampung Majapahit, these activities also have an impact on the number of tourist visits at the homestay. However, to give a positive impression for tourists who want to stay at homestays, proper 
management is needed. Regarding this matter, Supriyadi (2019) and the Secretary of the Bejijong Village Homestay Association (Enik, 2019) explained that the homestay management mechanism was carried out centrally, independently and there was a distribution of homestays to serve guests who wanted to stay using a rolling system. This is done to equalize the income of the homestay manager. In addition, regular coordination and training meetings are also held to standardize services and minimize conflicts as well as comparative studies in other areas to obtain development ideas.

The establishment of the Homestay association was originally intended as a forum for the community to make the Majapahit House as a Homestay. Over time, Homestay association also has a role that is more like a coordination center for all homestays in Bejijong Village, so that price competition and consumer conquest do not occur. In addition to economic factors, according to Supriyadi, the establishment of Homestay association is expected to help introduce and revive the tourism potential of Bejijong Village through customer experience. Moreover, Homestay association members also have a thought regarding the existence of Kampung Majapahit, namely so that Bejijong Village can have its own charm for tourists and can be known internationally through its uniqueness.

However, the dreams of the studio chair and members of the homestay community are certainly not easy to realize. The reason is the intense competition in today's business environment has resulted in companies or profit organizations having to have a competitive advantage to be able to survive. Basically, competitive advantage comes from various factors that distinguish it from competitors through creating a pleasant experience for customers (Erna, et.al., 2015). The experience in question is related to customer experience. According to Shaw (2007) customer experience has become a standard in business and through experience can create unique value for customers that is difficult to imitate by competitors and has a strong effect on satisfaction, loyalty and consumer recommendation behavior (Berry, et.al., 2002; Pine., et.al., 1999).

The concept of customer experience itself appears in several disciplines. The first discipline is seen from the perspective of sociology and psychology which explains that the peak experience is a real subjectivity, a very interesting, rich and complete experience that has been experienced by a person (Thorne, quoted in Wall, et al., 2011:11). The second discipline can be seen from the perspective of anthropology and ethnology which explains that experience means a medium to convey culture to individuals through events that are manifested by individuals themselves (Caru, et.al, 2003) and others, society and world society (Abrahams, cited in Wall, et al., 2011:11). Likewise, Pine, et.al. (1999) stated in his research that a successful experience occurs when consumers get something unique, memorable, sustainable, eager to be repeated and developed, and make consumers enthusiastic to do WOM 
(word of mouth). While the third discipline can be viewed from the perspective of economics and marketing proposed by Schmitt (1999) who views that experience is personal; it is an individual response that occurs to some stimuli and involvement in a particular setting or background. In this case, the marketer (manager) must offer the facilities and environment to create the desired customer experience. Lewis, et al. (2000) define customer experience as the total implication of the combination of environment, goods and services purchased by customers.

\section{RESEARCH METHODS}

This study used a qualitative method with a phenomenological paradigm. As a scientific discipline, phenomenology studies the structure of experience and consciousness. In literal, phenomenology is the study of phenomena, such as appearances, things that appear in our experiences, the way we experience things, and the meanings we have in our experiences. The focus of attention on phenomenology is not just a phenomenon, but a conscious experience from the point of view of the first person or who has experienced it directly (Kuswarno, 2009:22). Phenomenology seeks to uncover, study and understand a phenomenon and its typical and unique context experienced by individuals to the level of the individual 'beliefs' concerned. This research was conducted to answer the main research question "What is the customer experience perspective in the management of the Majapahit House in Bejijong Village, Mojokerto?

In determination of the interviewees at the research Perspective Customer Experience in the Management of Houses in the village Bejijong, Mojokerto based on the involvement of resource persons in the Majapahit House service as described in table 3.

Table 3. Classification of Target Personnel

\begin{tabular}{lll}
\hline \multicolumn{1}{c}{ Position/ Position } & \multicolumn{1}{c}{ Function } & Subject \\
\hline Traveler & $\begin{array}{l}\text { Actors who directly feel the } \\
\text { sensation of staying at the Majapahit }\end{array}$ & SA \\
& $\begin{array}{l}\text { House } \\
\text { Actors who directly act as the center }\end{array}$ & EN \\
Chairman & of tourism management in Bejijong & \\
Bhagaskara Studio & Village & \\
Secretary of the Bejijong & $\begin{array}{l}\text { Actors who are directly responsible SU } \\
\text { Village Homestay Association }\end{array}$ & for the management of the homestay
\end{tabular}

Source: Research data, processed (2020)

According to Moustakas (1994) there are several core processes in the analysis of phenomenological research, including: epoche, reduction, imaginative variation, and synthesis of meanings and essences.

Epoche 
The process of eliminating prejudice, reducing bias and opinions towards something. In this case, it focuses on the way of seeing and paying attention to something, increasing sensitivity, without involving the researcher's prejudice on the phenomena that are seen, thought, imagined or felt.

\section{Phenomenological Reduction}

In this process, the researcher's task is to describe in textural language (patterned language) what a person has seen, not only external objects but also internal actions of consciousness, the experience itself, such as rhythm and the relationship between the phenomenon (the phenomenon under study). and self.

\section{Imaginative Variation}

The task in the process of imaginative variation is to search for possible meanings through the use of imagination, different frames of reference, grouping and reversal, and approach to the phenomenon from divergent perspectives, positions, roles, or functions.

\section{Synthesis of Meanings and Essences}

The final step is the fundamental integration of textural and structural descriptions into one comprehensive description of the meaning and essence of the experiences of the subjects. Essence means something general or universal, a condition or quality in which something will not be something itself (Husserl in Moustakas, 1994).

\section{RESULTS AND DISCUSSIONS}

\section{Epoche}

At first, the researchers sought information on phenomena that occurred in various media and journals. After obtaining sufficient information, the researcher conducted interviews with 5 (five) research subjects and made transcriptions.

\section{Phenomenological Reduction}

After careful observing, bracketing was carried out from the interview transcript. In this case, the researcher omitted various statements from the research subject that were repetitive and outside the topics discussed.

\section{Imaginative Variation}

At this stage, the researcher first examined the interview transcript again to find the themes that formed the phenomenon. After looking at the interview transcript, the researcher then determined the theme. Determination of the theme in this study was determined by reference to the concept of the gap model of service quality proposed by Parasuraman, et.al. (1985) as a foundation for thinking. 
Through the results of re-examining line by line on the transcript and exploring the model proposed by Parasuraman, et.al. (1985), researchers found several new themes forming customer experience that had not previously been discussed in the gap model of Service Quality. Some of these things include the expectation of a good service and the involvement of the community/agencies from the perspective of the service provider.

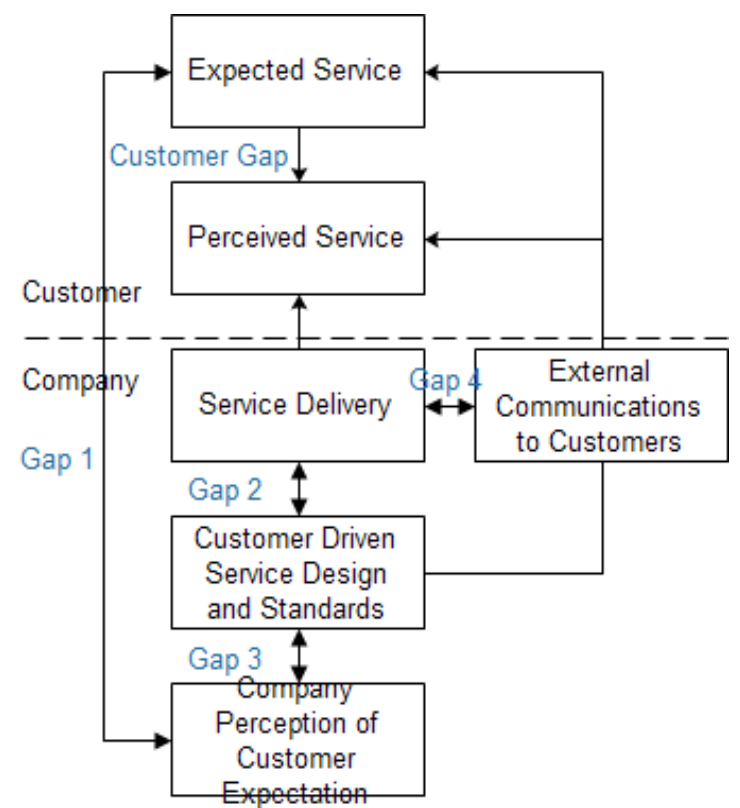

Figure 1. Gaps Model of Service Quality

Source: Parasuraman, et.al. (1985)

Through the themes that have been found, the researcher then makes an in-depth description of the themes. The following is a description of the themes that were found in this research:

1. Expectations - expectations in this study can be interpreted as what is thought by consumers to be provided by the service provider. In other words, the expectations in this study are the standards held by tourists to feel satisfied. Based on the findings from the interview process, each tourist has different expectations. These expectations arise from various things such as experiences and information from various media. In SA and PA, they have expectations that are based on the experience of staying at a guest house. While the third research subject has expectations based on information from various media such as the OYO lodging provider application. In this matter, expectations along with perceptions (the 3rd theme) will be interconnected. The difference between these two themes will create gaps as found in this study. Although the three interviewees felt the same service, they had different perceptions of the services 
provided. This is due to the different expectation factors among the three research subjects (tourists).

2. Perception - in this study, the researcher divides perception into two perspectives. First, from the perspective of tourists, self-perception can be interpreted as a subjective assessment by customers of their experience of consuming goods/services. Meanwhile, from the perspective of service providers, perception can be interpreted as management's perception of consumer desires. Self-perception appears after the service is provided. At this stage, there is a comparison between expectations and the services provided, giving rise to perceptions. The nature of perception is subjective. This is due to differences in expectations that become the standard of service for tourists. The higher the expectations of tourists, the higher the demands of the tourists to feel satisfied with the services provided. This is evidenced by the perceptions of the three informants regarding the first impression of seeing the Majapahit House. Although in terms of buildings and facilities owned by all Majapahit House, only 2 (two) research subjects (tourists) were amazed. Meanwhile, 1 (one) other tourist was disappointed because it did not match what was imagined.

3. Community/institutional involvement - this study highlights community/ institutional involvement as one of the themes that shape the phenomenon. This is because the involvement of the community/ institution will partially have an impact on the services provided. In addition, according to SU, the form of business of Majapahit House is a community-based business. So that community involvement becomes very important to support the creation of a perfect service. Meanwhile, the involvement of agencies is more directed at providing facilities and debriefing to human resources/community.

4. Service provided/received - in this study the researcher defines service as everything that is done and prepared by service providers to tourists. The service itself can refer to human resources, activities, $F \& B$ as well as facilities and infrastructure. At the service delivery stage, the customer experience is automatically formed. This will automatically trigger a perception of the services provided.

5. Management - researchers conclude management as a process of planning, mobilizing, organizing and directing people to make appropriate use of available materials and facilities to achieve common goals. The goal in this study is a positive customer experience. In addition, in this study the management also talks about service quality specifications which include infrastructure, human resources and matters relating to service delivery.

\section{Synthesis of Meanings and Essences}

In this study, the focus of the phenomenon is customer experience. Customer experience is identified as an important event that 
will be explored how its role is as a determinant of the success of a service. This research looks at the things that make up experience from two perspectives. The first point of view is the customer starting from expectations, perceived service, perceptions and expectations. While the second point of view is from the service provider where management, involvement and perception will trigger the services provided.

The phenomenon of customer experience itself has a special nature inherent in it that affects an action. So that, through this trait it will be used as a reference for providing services. From the results of imaginative variation, the theme of expectations becomes the context that explains the phenomenon of customer experience. In other words, expectations have a certain special trait or characteristic. One form of the characteristic that is found in this study is the thought by consumers and should be provided by the service provider. This is what consumers think about which then becomes the standard of a service. Every tourist will of course have different expectations for the service that will be felt. When expectations exceed perception there will be a gap and trigger a bad experience. Conversely, if expectations are below perception, it will trigger a good experience and behavior to recommend the service to others.

In this study, expectations are the context because expectations are situations that affect an action, as well as being the beginning of an existing phenomenon. Based on the results of interviews, visitors have various expectations of the existence of the Majapahit House. Regarding expectations, the three tourists who were used as resource persons agreed that tourist expectations arise from comparing previous experiences and information from various media. SA has expectations based on her experience of staying at homestays (residents' homes). Thus, he had an expectation that the Majapahit House would be like staying at a resident's house like in general. The second resource person, ME has expectations based on information from online media such as the OYO application. According to ME, the Majapahit House must be like an inn in general, like the OYO application. While the third interviewee, PA have expectations that are based on past experience. In addition, PA also has an expectation that the Rumah Majapahit homestay has the ambience and vibes of the royal era as mentioned by various media.

Phenomena that have been identified along with their nature/context will then be found actions/interactions aimed at deal with, cope with, implement or respond to the phenomenon. At this point there are two themes that refer to the form of action strategies for a phenomenon, namely the service and management theme. Some of the interactions in management identified include brainstorming, starting from the submission of opinions/findings/constraints/progress/ideas encountered in the field or perhaps submitting complaints from visitors. In the other side, several interview subjects also conveyed the same thing, for example the interaction in the form of coordination/evaluation meetings 
held every month and briefings when there were guests. Through coordination/ evaluation meetings and briefings, it is hoped that they can evaluate each other's behavior or steps that have been inappropriate so far, so that a solution can be obtained that can prevent the same mistakes from happening in the future. The second theme included in the strategy of action and interaction is service. Several interactions in management identified include the process of delivering services from service providers to visitors such as batik activities, walks to various tourist attractions, cycling, attractions to typical lodging places.

The success of the management is influenced by two themes, namely perception and involvement of the community/agencies. These two themes can be classified as influencing conditions that can facilitate or hinder the action/interaction strategy undertaken. First, in this study the perception in question is the perception of service providers to understand the perceptions of visitors. Perception will be the basis for service providers to develop and strengthen services and management. Examples of perceptions from this study are statements from service providers regarding various negative responses from visitors regarding homestay facilities such as air conditioning, bathrooms, cleanliness and breakfast. This is one of the thing that the service provider tries to fix by starting a coordination and evaluation meeting.

The second is the theme of community/institutional involvement. This theme also has an important influence on management. Based on information from interviews conducted with tourists, the community has an important role in creating positive perceptions and experiences for visitors. For example, when PA saw people wearing kebaya (Javanese traditional costume for woman). Furthermore, as stated by $\mathrm{SU}$, the involvement of the community such as homestay managers and youth (for guides) as well as children also have a very important role. As for the agency, it is more for assistance in the form of supplies, finance and facilities. This is shown by the involvement of Bank Indonesia, which helps provide mattresses, bed linen, cupboards and the construction of an information center. Meanwhile, from the University of Surabaya, it was more of a briefing by conducting comparative studies in Tourism Villages in Banyuwangi and supporting the implementation of the festival.

During the service delivery process (service theme) a customer experience will appear which then triggers perceptions and expectations. The first is the perception from the customer's perspective. Tourists have different perceptions of the services provided. On the SA interviewees, the perception obtained is that they are satisfied with the services provided, and it is not uncommon for SA to praise the various services they receive. In addition, the impact of the services provided made SA want to return to Bejijong for a vacation. The second informant, ME had the opposite response. The experience that makes ME have a bad perception is the form of the program that is less interactive and the atmosphere of 
the room is dirty. This made ME to think again about making a visit to Bejijong Village. The third resource person, PA has a response that tends to be neutral. Sometimes PA conveys admiration and positive reactions to the architecture of the building and the culture that is rooted in its people. However, sometimes PA conveys the impression of being dissatisfied with the non-standard services between homestays.

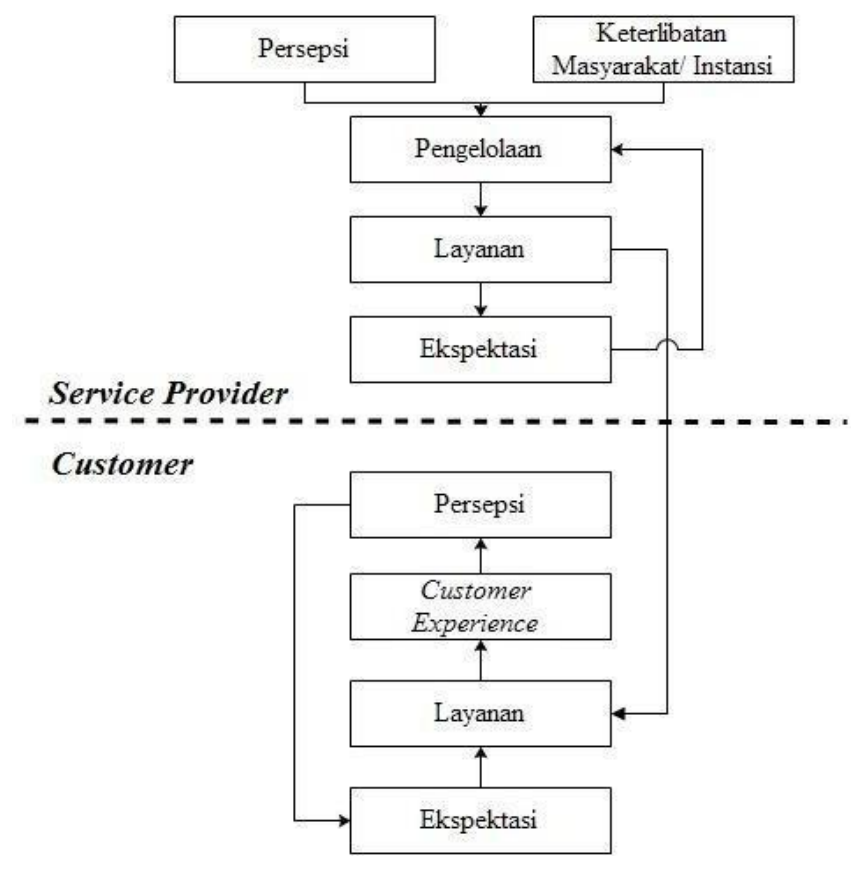

Figure 2. Customer Experience Model

Source: Processed Researcher Data (2020)

The second theme is hope. The theme of hope appears after visitors or managers see and feel the services that exist. On this theme, all the speakers have hope for better service. Based on the results of interviews conducted, the expectations of visitors and managers have several things in common. Some of these things are related to facilities and infrastructure. The facilities in question are the availability of bathrooms and modes of transportation. The main problem with the facilities is the location of the bathroom which is far away (separate from the Majapahit House). Besides, the problem of transportation is related to the availability of bicycles. In this case, PA and ME have the hope of being able to return to the Majapahit House only if the management has resolved the problems related to the bathroom. While subjective expectations from managers are more inclined to increase the number of tourists and further development. Moreover, through hope, new expectations will emerge. In this study, SA has an expectation that when he stays at the Majapahit House for the second time, he will receive at least the same service as when he stayed for the first time. Thus, through perception will trigger hope and hope will trigger new expectations based 
on previous experiences. Table 4 shows a summary of tourist responses the Majapahit House.

After the researcher explained the relationship between the themes, the next step was to visualize it into an image. Figure 2 shows a summary of the explanation of the relationship between themes. At this stage, the researcher had previously shown and explained the illustration of the relationship between themes to the manager to confirm the correctness of the current service flow.

Table 4. Summary of Responses of Research Subjects (Tourists)

\begin{tabular}{|c|c|c|c|c|}
\hline \multirow[t]{2}{*}{ Responses Done } & \multicolumn{4}{|c|}{ Research Subject } \\
\hline & & & $\mathrm{ME}$ & PA \\
\hline Share experiences on social media & $\sqrt{ }$ & $\sqrt{ }$ & & $\sqrt{ }$ \\
\hline Recommend to colleagues/friends/family & $\sqrt{ }$ & $\mathrm{X}$ & & $\mathrm{X}$ \\
\hline Will definitely come back & $\sqrt{ }$ & $\mathrm{X}$ & & $\mathrm{X}$ \\
\hline Would come back if.... & $\mathrm{X}$ & $\sqrt{ }$ & & $\sqrt{ }$ \\
\hline
\end{tabular}

\section{CONCLUSION}

The phenomenon of customer experience is explored based on three conditions, namely pre, experiencing the journey and post. The three conditions are clarified by answering the problem formulation from the point of view of various research subjects.

First, the pre-condition, this condition leads to expectations. In this study, it is explained that expectations are what consumers think that must be provided by service providers. So, the nature of expectations is subjective. In addition, partially expectations will affect perceptions. This happens because expectations are the standard for tourists to feel satisfied with a service. Expectations can arise from two sources, namely past experience of the same type of service and information from various media. In general, tourists' expectations of the Majapahit House tend to vary. SA has expectations regarding the Majapahit House like villages in general. ME expects lodging locations to be similar to those available on the OYO application. Meanwhile, PA has expectations by comparing the experience of vacationing in other tourist villages.

Both conditions are experiencing the journey, this condition leads to service, management and community/institutional involvement. In the service delivery process, the customer experience will automatically be formed. So related to this it is necessary to have proper service management from service providers. In the management of services cannot be separated from the involvement of the community/ agencies. This happens because the form of business of Majapahit House is a community-based business. Thus, the community has a very big role to influence the customer experience.

Both conditions are experiencing the journey, this condition leads to 
service, management and community/institutional involvement. In the service delivery process, the customer experience will automatically be formed. So related to this it is necessary to have proper service management from service providers. In the management of services cannot be separated from the involvement of the community/ agencies. This happens because the form of business of Majapahit House is a community-based business. Then, the community has a very big role to influence the customer experience. Moreover, the nature of perception is subjective. This is influenced by the expectation factor. The higher the expectation, the more difficult it will be for tourists to have a positive perception of service. After tourists have a perception of a service, expectations will appear (post conditions).

This study found that the intended expectation is a situation where a person has a positive motivation towards future desires. In regard to this, the desire in question is the goal. For service providers, expectations arise after the service provider knows how tourists react to the service. In addition, hope for service providers can also arise because of the dreams they want to realize related to business development. Furthermore, this study found that expectations that arise as a result of perception will trigger new expectations. This happens when tourists have hopes of visiting the same place in the future, so they will have expectations based on previous experiences.

Additionally, this study also found several statements that were often uttered by EN and SU. The statement has nothing to do with the research question or customer experience. The statement is a story about the history of the establishment of Kampung Majapahit, specifically the establishment of 600 Majapahit House in the Trowulan area. According to them, the history of the Majapahit House is an important thing to remember because it talks about the initial purpose of the establishment of Kampung Majapahit to become a Majapahit cultural tourism village.

By seeing all the limitations contained in this research, it is clear that there are many areas/spaces that can still be explored for further research in the future. First, the limitation of this study is using Parasuraman,et.al. (1985) as the main reference. As a result, this research is not able to describe the consumer behavior related to the assessment and decision making based on the stages. Through the addition of consumer behavior literature, this research will be richer and able to describe the existing phenomena in more detail based on five stages of assessment and decision making, including: problem recognition; information search; evaluate alternatives; buying decision; and post- purchase evaluation. Second, the limitation of this research is that it uses resource persons who are visiting the Majapahit House for the first time. So the results of this study cannot provide a comparison of perceptions from the same resource person regarding services at different times. So for further research, researchers can add literature on consumer behavior and add resource persons who have previously experienced 
services at the Majapahit House.

\section{ACKNOWLEDGMENTS}

I would like to express my deepest gratitude to Mrs. Erna as my mentor in completing this research and to all parties that I cannot mention one by one.

\section{REFERENCES}

Ali, F., et.al. (2014). Memorable Customer Experience: Examining the Effects of Customers Experience on Memories and Loyalty in Malaysian Resort Hotels, Social and Behavioral Sciences 144 (2014) p. 273-279.

Andajani, E., Hadiwidjojo, Djumilah, Rahayu, Mintarti, Djumahir (2015) Customer Experience Model: Social Environment, Retail Brand and Positive WOM. Research in Business and Management, 2 (1). pp. 25-41.

Ardika, I, W. (2003). Pariwisata Budaya Berkelanjutan, Refleksi dan Harapan di Tengah Perkembangan Global. Tesis. Program Pascasarjana Universitas Udayana Bali.

Ariastita, T. A. (2014). Arahan Pengembangan Kota Palembang Sebagai Kota Pusaka . JURNAL TEKNIK POMITS Vol. 3, No.2, , 212-217.

Berry, Leonard L., Kathleen Seiders, and Dhruv Grewal (2002),-_Understanding Service Convenience," Journal of Marketing, 66 (July), 1-17

Caru, A. \& Cova, B. (2003). Revisiting consumptionexperience: A more humble but complete view of the concept. Marketing Theory 3(2) (p.267-286).

Husserl, E. (1931). Ideas: general introduction to pure phenomenology.

Kuswarno, E. (2009). Metodologi Penelitian Komunikasi Fenomenologi: Konsepsi, Pedoman dan Contoh Penelitian Fenomena Pengemis Kota Bandung. Bandung: Widya Padjadjaran.

Lewis, B.R. \& Soureli, M. (2006). The antecedents of consumer loyalty in retail banking. Journal of Consumer Behaviour. 5 (1), 15-31.

Moustakas, C. E. (1994). Phenomenological research methods. Sage Publications, Inc.

Parasuraman, A. and Valarie A., Zeithaml (1982). "Differential Perceptions of Supplier and Clients of Industrial Sevices," in Emerging Perspectives on Services Marketing.

Pine, J. \& Gilmore, J. (1999). The Experience Economy, Harvard Business School Press, Boston.

Rencana Induk Pembangunan Pariwisata Daerah RIPPDA Kabupaten Mojokerto tahun 2007 tentang wisata budaya dan peninggalan sejarah.

Robinnete, S., \& C. Brand. (2008). Emoticon marketing. US : McGrow Hill. Schmitt, B. H. (1999), Experiential Marketing. New York, NY: Free Press.

Rubin, A., \& Babbie, E. R., (2008), Research Methods for Social Work, sixth edition, Thomson Brooks/Cole, Belmont.

Walls, Andrew, Okumus, Fevzi, Wang, Youcheng and Kwun, David, J. W. 2011. Understanding the Consumer Experience: An Exploratory Study of Luxury Hotels', Journal of Hospitality Marketing \&Management, 20: 2, 166 $-197$. 